\title{
Synthesis and crystal structure of the double cluster $\left[\mathrm{Cp}_{3} \mathrm{Fe}_{4}(\mathrm{CO})_{4}\left(\mathrm{C}_{5} \mathrm{H}_{4}\right)\right]_{2}\left(p-\mathrm{C}_{6} \mathrm{H}_{4}\right)$ is
}

\author{
Wen-Yann Yeh ${ }^{\mathrm{a}, *}$, Yen-Chung Liu ${ }^{\mathrm{a}}$, Shie-Ming Peng ${ }^{\mathrm{b}}$, Gene-Hsiang Lee ${ }^{\mathrm{b}}$ \\ a Department of Chemistry, National Sun Yat-Sen University, 70 Lan-Hai Road, Kaohsiung 804, Taiwan \\ b Department of Chemistry, National Taiwan University, Taipei 106, Taiwan
}

Received 12 September 2003; accepted 25 December 2003

\begin{abstract}
$\left[\mathrm{Cp}_{4} \mathrm{Fe}_{4}(\mathrm{CO})_{4}\right]$ (1) reacts with $p-\mathrm{BrC}_{6} \mathrm{H}_{4} \mathrm{Li}$ and $\mathrm{MeOH}$ in sequence to afford the functionalized cluster $\left[\mathrm{Cp}_{3} \mathrm{Fe}_{4}(\mathrm{CO})_{4}\left(\mathrm{C}_{5} \mathrm{H}_{4}-p-\right.\right.$ $\left.\left.\mathrm{C}_{6} \mathrm{H}_{4} \mathrm{Br}\right)\right](2)$, while the reaction of 2 with $n$ - $\mathrm{BuLi}$ and $\mathrm{MeOH}$ produces $\left[\mathrm{Cp}_{2} \mathrm{Fe}_{4}(\mathrm{CO})_{4}\left(\mathrm{C}_{5} \mathrm{H}_{4} \mathrm{Bu}\right)\left(\mathrm{C}_{5} \mathrm{H}_{4}-p-\mathrm{C}_{6} \mathrm{H}_{4} \mathrm{Br}\right)\right](3)$. The double cluster $\left[\mathrm{Cp}_{3} \mathrm{Fe}_{4}(\mathrm{CO})_{4}\left(\mathrm{C}_{5} \mathrm{H}_{4}\right)\right]_{2}\left(p-\mathrm{C}_{6} \mathrm{H}_{4}\right)(4)$ has been prepared by treatment of $\left[\mathrm{Cp}_{4} \mathrm{Fe}_{4}(\mathrm{CO})_{4}\right]$ with $p-\mathrm{C}_{6} \mathrm{H}_{4} \mathrm{Li}_{2}$ and $\mathrm{MeOH}$ in sequence. The electrochemistry of $\mathbf{2}$ and $\mathbf{4}$, as well as the crystal structure of $\mathbf{4}$ have been investigated.
\end{abstract}

(C) 2004 Elsevier B.V. All rights reserved.

Keywords: Iron; Tetrairon cluster

\section{Introduction}

$\left[\mathrm{Cp}_{4} \mathrm{Fe}_{4}(\mathrm{CO})_{4}\right](\mathbf{1})$, originally reported by King [1], is one of the first substance containing a tetrahedral cluster of metal atoms. A unique feature of this stable cluster is that it is electroactive, reversibly undergoing both reduction and oxidation [2,3], which property is essential to perform important functions such as solar energy conversion and multielectron catalysis [4,5]. Recently, assembling higher nuclearity clusters with well-defined dimensions provides a new field of chemistry with prospective application in areas including molecular recognition and nanotechnology [6-10]. It is therefore of interest to construct oligomers of $\mathbf{1}$ and study their electroactivity [11]. We have previously prepared the double clusters $\left[\mathrm{Cp}_{3} \mathrm{Fe}_{4}(\mathrm{CO})_{4}\left(\mathrm{C}_{5} \mathrm{H}_{4}\right)\right]_{2}$ and $\left[\mathrm{Cp}_{3} \mathrm{Fe}_{4}\right.$ $\left.(\mathrm{CO})_{4}\left(\mathrm{C}_{5} \mathrm{H}_{4}\right)\right]_{2} \quad\left[\left(\mathrm{C}_{5} \mathrm{H}_{4}\right)_{2} \mathrm{Fe}\right]$ by treating the anion $\left[\mathrm{Cp}_{3} \mathrm{Fe}_{4}(\mathrm{CO})_{4}\left(\mathrm{C}_{5} \mathrm{H}_{4}\right)\right]^{-}$with 1 and dibromoferrocene, respectively [12]. Now we report an arene-bridged dou-

\footnotetext{
Supplementary data associated with this article can be found, in the online version, at doi:10.1016/j.jorganchem.2003.12.040.

${ }^{*}$ Corresponding author. Tel.: +886752520003927; fax: +886752 53908.

E-mail address: wenyann@mail.nsysu.edu.tw (W.-Y. Yeh).
}

ble cluster $\left[\mathrm{Cp}_{3} \mathrm{Fe}_{4}(\mathrm{CO})_{4}\left(\mathrm{C}_{5} \mathrm{H}_{4}\right)\right]_{2}\left(p-\mathrm{C}_{6} \mathrm{H}_{4}\right)(4)$ but with a different synthetic approach.

\section{Results and discussion}

Compound 1 reacted with $p-\mathrm{BrC}_{6} \mathrm{H}_{4} \mathrm{Li}$ and $\mathrm{MeOH}$ in sequence to afford the functionalized cluster $\left[\mathrm{Cp}_{3} \mathrm{Fe}_{4}-\right.$ $\left.(\mathrm{CO})_{4}\left(\mathrm{C}_{5} \mathrm{H}_{4}-p-\mathrm{C}_{6} \mathrm{H}_{4} \mathrm{Br}\right)\right]$ (2) in $30 \%$ yield (Eq. (1)), where the nucleophile $p-\mathrm{BrC}_{6} \mathrm{H}_{4}^{-}$added to a cyclopentadienyl ring of 1 . It was thought that subsequent treatment of 2 with $n$-BuLi might abstract the bromine atom to generate $\left[\mathrm{Cp}_{3} \mathrm{Fe}_{4}(\mathrm{CO})_{4}\left(\mathrm{C}_{5} \mathrm{H}_{4}-p-\mathrm{C}_{6} \mathrm{H}_{4}\right)\right]^{-}$, which can then react with 1 to produce 4 . In fact, the $n-\mathrm{Bu}^{-}$anion attacked a separate $\mathrm{Cp}$ group to produce $\left[\mathrm{Cp}_{2} \mathrm{Fe}_{4}(\mathrm{CO})_{4^{-}}\right.$ $\left.\left(\mathrm{C}_{5} \mathrm{H}_{4} \mathrm{Bu}\right)\left(\mathrm{C}_{5} \mathrm{H}_{4}-p-\mathrm{C}_{6} \mathrm{H}_{4} \mathrm{Br}\right)\right]$ (3) in $40 \%$ yield (Eq. (2)). A reverse way by treating 2 with the anion $\left[\mathrm{Cp}_{3} \mathrm{Fe}_{4}\right.$ $\left.(\mathrm{CO})_{4}\left(\mathrm{C}_{5} \mathrm{H}_{4}\right)\right]^{-}$did not afford 4 , too. We then prepared the dianion $p-\mathrm{C}_{6} \mathrm{H}_{4} \mathrm{Li}_{2}$ by treating $p-\mathrm{C}_{6} \mathrm{H}_{4} \mathrm{Br}_{2}$ with two equivalent of $n$-BuLi [13], which reacted with $\mathbf{1}$ and $\mathrm{MeOH}$ in sequence to give 4 in $24 \%$ yield after purification by column chromatography and crystallization (Eq. (3)). In these reactions, however, the starting clusters were recovered in $48-57 \%$ yield even though the reactions monitored by IR showed no presence of them 
after introduction of the nucleophiles. Since these carbonyl clusters are easily reduced, as the electrochemical studies have shown, reduction of them probably competes with nucleophilic addition here and limits the yields of products [11]
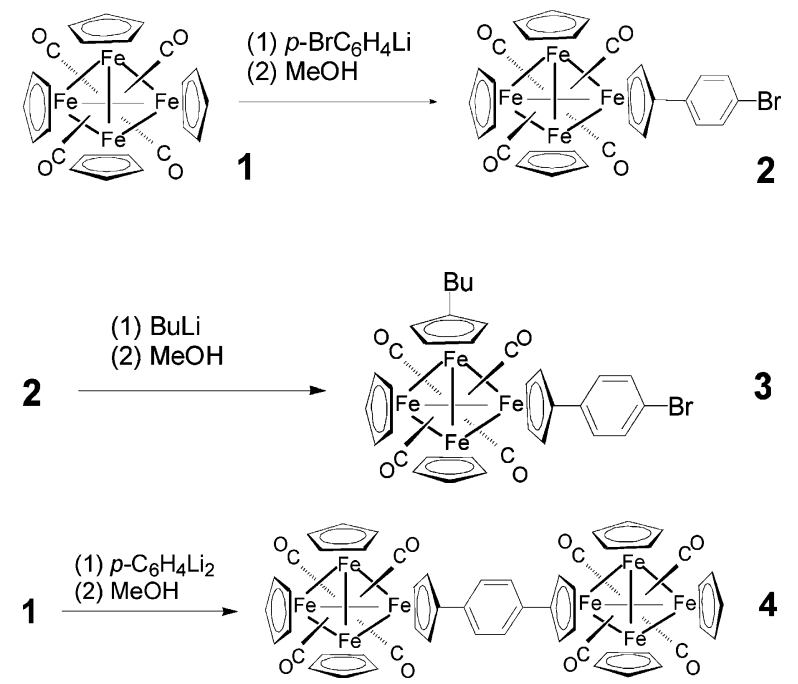

The new clusters $\mathbf{2 - 4}$ form air-stable, dark green crystalline solids which have been characterized by elemental analyses, mass, IR and NMR. Their IR spectra in the carbonyl region present one broad absorption around $1635 \mathrm{~cm}^{-1}$ for the triply bridging carbonyl ligands, suggesting that their tetrahedral iron cores remain intact. Their ${ }^{1} \mathrm{H}$ NMR spectra are closely related, where the unsubstituted $\mathrm{Cp}$ groups display a singlet resonance at ca. $4.5 \mathrm{ppm}$ and each substituted $\mathrm{C}_{5} \mathrm{H}_{4}$ group shows two sets of multiplet resonances in the range $4.9-4.3 \mathrm{ppm}$. The $\mathrm{C}_{6} \mathrm{H}_{4} \mathrm{Br}$ group in 2 and 3 presents two doublet resonances at 7.6 and $7.5 \mathrm{ppm}$, while the bridging $\mathrm{C}_{6} \mathrm{H}_{4}$ group of $\mathbf{4}$ shows a singlet resonance at $7.78 \mathrm{ppm}$. The ${ }^{13} \mathrm{C}\left\{{ }^{1} \mathrm{H}\right\}$ NMR spectrum of $\mathbf{2}$ displays the triply bridging carbonyl signals at 290.8 and 290.5 ppm in an approximate ratio of 1:3, four signals for the $\mathrm{C}_{6} \mathrm{H}_{4} \mathrm{Br}$ group in the range 131.5-122.3 ppm, three signals for the $\mathrm{C}_{5} \mathrm{H}_{4}$ group at 104.4, 100.6 and $95.2 \mathrm{ppm}$, and the $\mathrm{Cp}$ group resonance at $99.1 \mathrm{ppm}$, consistent with a molecule of idealized $C_{s}$ symmetry in solution.

The molecular structure of $\mathbf{4}$ is illustrated in Fig. 1. Selected bond distances and bond angles are collected in Table 1. There is a crystallographic center of symmetry imposed on the molecule. The coordination about each $\mathrm{Fe}_{4}$ cluster shows great resemblance to that of $\mathbf{1}[14,15]$. The two $\mathrm{Fe}_{4}$ clusters are located in opposite sides of the $\mathrm{C}_{5} \mathrm{H}_{4}-\mathrm{C}_{6} \mathrm{H}_{4}-\mathrm{C}_{5} \mathrm{H}_{4}$ link. The two $\mathrm{C}_{5} \mathrm{H}_{4}$ groups are about coplanar, while the bridging $\mathrm{C}_{6} \mathrm{H}_{4}$ group is tilted from the plane by $11.5^{\circ}$. The average $\mathrm{Fe}-\mathrm{Fe}$ lengths and $\mathrm{Fe}-$ $\mathrm{C}(\mathrm{Cp})$ lengths are 2.52 and $2.12 \AA$, respectively. The individual $\mathrm{Fe}-\mathrm{CO}$ distances range from 1.964(3) to 1.999(3) $\AA$ and the $\mathrm{C}-\mathrm{O}$ distances from 1.197(4) to 1.202(4) $\AA$, while $\mathrm{Fe}-\mathrm{C}-\mathrm{O}$ angles are in the range 131.7(2) ${ }^{\circ}-134.6(2)^{\circ}$. The $\mathrm{C}-\mathrm{C}$ bond lengths within the cyclopentadienyl and bezene rings are averaged 1.42 and $1.39 \AA$, respectively, and the $\mathrm{C}(9)-\mathrm{C}(10)$ length is $1.470(4) \AA$.

Cyclic voltammogram studies of $\mathbf{2}$ and $\mathbf{4}$ were taken in dry, oxygen-free $\mathrm{CH}_{2} \mathrm{Cl}_{2}$ at $27{ }^{\circ} \mathrm{C}$. The $E_{1 / 2}$ values (versus $\mathrm{Cp}_{2} \mathrm{Fe} / \mathrm{Cp}_{2} \mathrm{Fe}^{+}$couple) relating each oxidation state are depicted in Scheme 1. Analogous to 1, compound $\mathbf{2}$ also exists in four electrochemically reversible oxidation states, $\left[\mathrm{Cp}_{3} \mathrm{Fe}_{4}(\mathrm{CO})_{4}\left(\mathrm{C}_{5} \mathrm{H}_{4}-p\right.\right.$ $\left.\left.\mathrm{C}_{6} \mathrm{H}_{4} \mathrm{Br}\right)\right]^{2+/+/ 0 /-}$, while the redox potentials are shifted anodically by $56-130 \mathrm{mV}$ due to the electron-withdrawing substituent. On the other hand, compound 4 displays three redox waves in correspondence to a $\mathbf{4}^{3+} \leftrightarrow \mathbf{4}^{2+} \leftrightarrow \mathbf{4}^{0} \leftrightarrow \mathbf{4}^{2-}$ transformation. The two-electron reduction (and oxidation) wave is likely the overlap of two closely spaced one-electron redox couples for each $\mathrm{Fe}_{4}$ cluster with slight electronic interactions between them, presumably because the $\mathrm{C}_{5} \mathrm{H}_{4}-\mathrm{C}_{6} \mathrm{H}_{4}-\mathrm{C}_{5} \mathrm{H}_{4}$ link is not planar and therefore is not in full conjugation $[16,17]$.

In summary, the double cluster 4 has been prepared by the reaction of $p-\mathrm{C}_{6} \mathrm{H}_{4} \mathrm{Li}_{2}$ with two molecules of $\mathbf{1}$. Since compound $\mathbf{1}$ is susceptible to two nucleophilic additions to form $\mathbf{3}$, it is promising that further treatment of 4 and 1 with $p-\mathrm{C}_{6} \mathrm{H}_{4} \mathrm{Li}_{2}$ or other dianionic

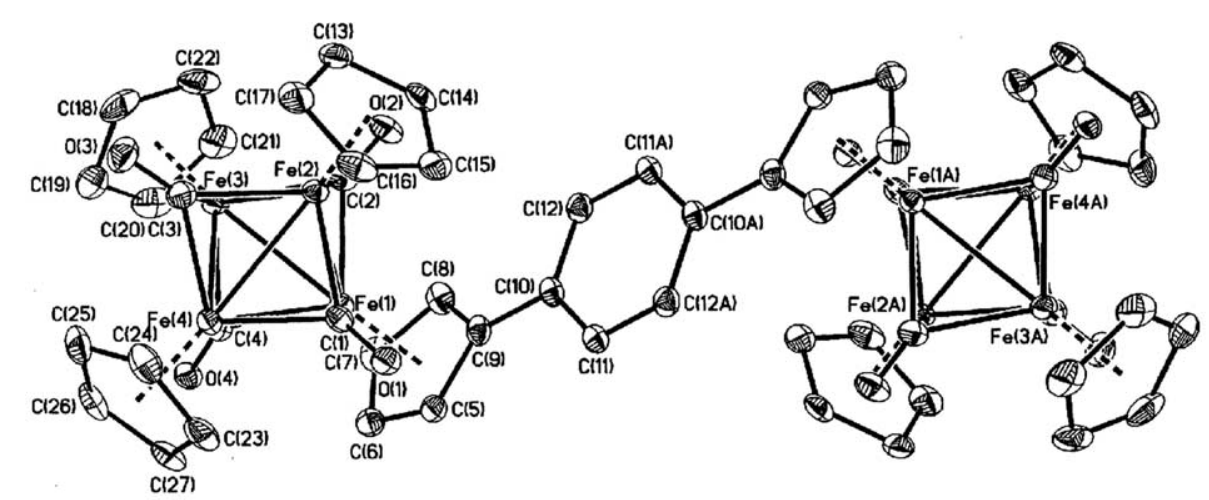

Fig. 1. Molecular structure of $\mathbf{4}$. The hydrogen atoms have been omitted for clarity. 
Table 1

Selected bond distances $(\AA)$ and bond angles $\left(^{\circ}\right)$ for $\mathbf{4}$

\begin{tabular}{|c|c|c|c|}
\hline \multicolumn{4}{|l|}{ Bond distances } \\
\hline $\mathrm{Fe}(1)-\mathrm{C}(2)$ & $1.979(3)$ & $\mathrm{Fe}(1)-\mathrm{C}(4)$ & $1.983(3)$ \\
\hline $\mathrm{Fe}(1)-\mathrm{C}(1)$ & $1.991(3)$ & $\mathrm{Fe}(1)-\mathrm{C}(7)$ & $2.102(3)$ \\
\hline $\mathrm{Fe}(1)-\mathrm{C}(6)$ & $2.108(3)$ & $\mathrm{Fe}(1)-\mathrm{C}(8)$ & $2.114(3)$ \\
\hline $\mathrm{Fe}(1)-\mathrm{C}(5)$ & $2.117(3)$ & $\mathrm{Fe}(1)-\mathrm{C}(9)$ & $2.137(3)$ \\
\hline $\mathrm{Fe}(1)-\mathrm{Fe}(4)$ & $2.5071(6)$ & $\mathrm{Fe}(1)-\mathrm{Fe}(3)$ & $2.5130(6)$ \\
\hline $\mathrm{Fe}(1)-\mathrm{Fe}(2)$ & $2.5168(6)$ & $\mathrm{Fe}(2)-\mathrm{C}(1)$ & $1.964(3)$ \\
\hline $\mathrm{Fe}(2)-\mathrm{C}(2)$ & $1.986(3)$ & $\mathrm{Fe}(2)-\mathrm{C}(3)$ & $1.991(3)$ \\
\hline $\mathrm{Fe}(2)-\mathrm{C}(13)$ & $2.109(3)$ & $\mathrm{Fe}(2)-\mathrm{C}(14)$ & $2.119(3)$ \\
\hline $\mathrm{Fe}(2)-\mathrm{C}(16)$ & $2.123(3)$ & $\mathrm{Fe}(2)-\mathrm{C}(15)$ & $2.123(3)$ \\
\hline $\mathrm{Fe}(2)-\mathrm{C}(17)$ & $2.123(3)$ & $\mathrm{Fe}(2)-\mathrm{Fe}(3)$ & $2.5120(6)$ \\
\hline $\mathrm{Fe}(2)-\mathrm{Fe}(4)$ & $2.5406(6)$ & $\mathrm{Fe}(3)-\mathrm{C}(4)$ & $1.968(3)$ \\
\hline $\mathrm{Fe}(3)-\mathrm{C}(2)$ & $1.980(3)$ & $\mathrm{Fe}(3)-\mathrm{C}(3)$ & $1.993(3)$ \\
\hline $\mathrm{Fe}(3)-\mathrm{C}(22)$ & $2.100(3)$ & $\mathrm{Fe}(3)-\mathrm{C}(21)$ & $2.105(4)$ \\
\hline $\mathrm{Fe}(3)-\mathrm{C}(19)$ & $2.111(3)$ & $\mathrm{Fe}(3)-\mathrm{C}(20)$ & $2.112(3)$ \\
\hline $\mathrm{Fe}(3)-\mathrm{C}(18)$ & $2.116(4)$ & $\mathrm{Fe}(3)-\mathrm{Fe}(4)$ & $2.5026(6)$ \\
\hline $\mathrm{Fe}(4)-\mathrm{C}(3)$ & $1.972(3)$ & $\mathrm{Fe}(4)-\mathrm{C}(4)$ & $1.987(3)$ \\
\hline $\mathrm{Fe}(4)-\mathrm{C}(1)$ & $1.999(3)$ & $\mathrm{Fe}(4)-\mathrm{C}(27)$ & $2.107(3)$ \\
\hline $\mathrm{Fe}(4)-\mathrm{C}(23)$ & $2.108(3)$ & $\mathrm{Fe}(4)-\mathrm{C}(24)$ & $2.113(3)$ \\
\hline $\mathrm{Fe}(4)-\mathrm{C}(26)$ & $2.116(3)$ & $\mathrm{Fe}(4)-\mathrm{C}(25)$ & $2.120(3)$ \\
\hline $\mathrm{O}(1)-\mathrm{C}(1)$ & $1.198(4)$ & $\mathrm{O}(2)-\mathrm{C}(2)$ & $1.197(4)$ \\
\hline $\mathrm{O}(3)-\mathrm{C}(3)$ & $1.201(4)$ & $\mathrm{O}(4)-\mathrm{C}(4)$ & $1.202(4)$ \\
\hline \multicolumn{4}{|l|}{ Bond angles } \\
\hline $\mathrm{Fe}(4)-\mathrm{Fe}(1)-\mathrm{Fe}(2)$ & $60.755(17)$ & $\mathrm{Fe}(3)-\mathrm{Fe}(1)-\mathrm{Fe}(2)$ & $59.924(17)$ \\
\hline $\mathrm{Fe}(4)-\mathrm{Fe}(1)-\mathrm{Fe}(3)$ & $59.802(18)$ & $\mathrm{Fe}(3)-\mathrm{Fe}(2)-\mathrm{Fe}(4)$ & $59.377(17)$ \\
\hline $\mathrm{Fe}(1)-\mathrm{Fe}(2)-\mathrm{Fe}(4)$ & $59.436(17)$ & $\mathrm{Fe}(1)-\mathrm{Fe}(2)-\mathrm{Fe}(3)$ & $59.965(17)$ \\
\hline $\mathrm{Fe}(4)-\mathrm{Fe}(3)-\mathrm{Fe}(2)$ & $60.879(17)$ & $\mathrm{Fe}(4)-\mathrm{Fe}(3)-\mathrm{Fe}(1)$ & $59.982(17)$ \\
\hline $\mathrm{Fe}(2)-\mathrm{Fe}(3)-\mathrm{Fe}(1)$ & $60.111(17)$ & $\mathrm{Fe}(3)-\mathrm{Fe}(4)-\mathrm{Fe}(2)$ & $59.744(17)$ \\
\hline $\mathrm{Fe}(1)-\mathrm{Fe}(4)-\mathrm{Fe}(2)$ & $59.810(17)$ & $\mathrm{Fe}(1)-\mathrm{Fe}(4)-\mathrm{Fe}(3)$ & $60.216(18)$ \\
\hline $\mathrm{O}(1)-\mathrm{C}(1)-\mathrm{Fe}(2)$ & $131.8(2)$ & $\mathrm{O}(1)-\mathrm{C}(1)-\mathrm{Fe}(1)$ & $133.4(3)$ \\
\hline $\mathrm{Fe}(2)-\mathrm{C}(1)-\mathrm{Fe}(1)$ & $79.03(12)$ & $\mathrm{O}(1)-\mathrm{C}(1)-\mathrm{Fe}(4)$ & $133.2(2)$ \\
\hline $\mathrm{Fe}(2)-\mathrm{C}(1)-\mathrm{Fe}(4)$ & $79.74(12)$ & $\mathrm{Fe}(1)-\mathrm{C}(1)-\mathrm{Fe}(4)$ & $77.86(11)$ \\
\hline $\mathrm{O}(2)-\mathrm{C}(2)-\mathrm{Fe}(1)$ & $133.8(3)$ & $\mathrm{O}(2)-\mathrm{C}(2)-\mathrm{Fe}(3)$ & $131.8(2)$ \\
\hline $\mathrm{Fe}(1)-\mathrm{C}(2)-\mathrm{Fe}(3)$ & $78.82(11)$ & $\mathrm{O}(2)-\mathrm{C}(2)-\mathrm{Fe}(2)$ & $133.0(2)$ \\
\hline $\mathrm{Fe}(1)-\mathrm{C}(2)-\mathrm{Fe}(2)$ & $78.80(12)$ & $\mathrm{Fe}(3)-\mathrm{C}(2)-\mathrm{Fe}(2)$ & $78.60(12)$ \\
\hline $\mathrm{O}(3)-\mathrm{C}(3)-\mathrm{Fe}(4)$ & $132.8(3)$ & $\mathrm{O}(3)-\mathrm{C}(3)-\mathrm{Fe}(2)$ & $132.4(3)$ \\
\hline $\mathrm{Fe}(4)-\mathrm{C}(3)-\mathrm{Fe}(2)$ & $79.76(12)$ & $\mathrm{O}(3)-\mathrm{C}(3)-\mathrm{Fe}(3)$ & $133.6(3)$ \\
\hline $\mathrm{Fe}(4)-\mathrm{C}(3)-\mathrm{Fe}(3)$ & $78.28(12)$ & $\mathrm{Fe}(2)-\mathrm{C}(3)-\mathrm{Fe}(3)$ & $78.19(12)$ \\
\hline $\mathrm{O}(4)-\mathrm{C}(4)-\mathrm{Fe}(3)$ & $134.6(2)$ & $\mathrm{O}(4)-\mathrm{C}(4)-\mathrm{Fe}(1)$ & $131.7(3)$ \\
\hline $\mathrm{O}(4)-\mathrm{C}(4)-\mathrm{Fe}(4)$ & $132.6(2)$ & $\mathrm{Fe}(3)-\mathrm{C}(4)-\mathrm{Fe}(4)$ & $78.53(12)$ \\
\hline $\mathrm{Fe}(1)-\mathrm{C}(4)-\mathrm{Fe}(4)$ & $78.32(11)$ & & \\
\hline
\end{tabular}

$$
\begin{aligned}
& \mathbf{1}^{2+} \underline{+628 \mathrm{mV}} \mathbf{1}^{+} \underline{-46 \mathrm{mV}} \mathbf{1} \stackrel{-1856 \mathrm{mV}}{\underline{1^{-}}}
\end{aligned}
$$

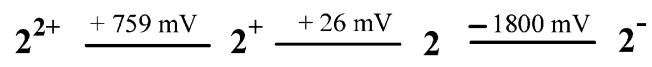

$$
\begin{aligned}
& \mathbf{4}^{3^{+}} \stackrel{+782 \mathrm{mV}}{-\mathbf{2}^{2+}+48 \mathrm{mV}} \mathbf{4} \stackrel{-1853 \mathrm{mV}}{\underline{2^{2-}}} \\
& \text { Scheme } 1 .
\end{aligned}
$$

nucleophiles could lead to higher cluster oligomers. The investigation is in progress in our laboratory.

\section{Experimental}

\subsection{General methods}

All manipulations were carried out under an atmosphere of purified dinitrogen with standard Schlenk techniques. $\left[\mathrm{Cp}_{4} \mathrm{Fe}_{4}(\mathrm{CO})_{4}\right](\mathbf{1})$ was prepared as described in the literature [12]. 1,4-dibromobenzene (from Aldrich) and $n$-butyl lithium (2.5 M in $n$-hexane, from Merck) were used as received. Solvents were dried over appropriate reagents under dinitrogen and distilled immediately before use. Infrared spectra were recorded with a $0.1 \mathrm{~mm}$ path $\mathrm{CaF}_{2}$ solution cell on a Hitachi I-2001 IR spectrometer. ${ }^{1} \mathrm{H}$ and ${ }^{13} \mathrm{C}$ NMR spectra were obtained on a Varian Unity INOVA-500 spectrometer at 500 and 125.7 $\mathrm{MHz}$, respectively. Fast-atom-bombardment (FAB) mass spectra were recorded on a JEOL JMS-SX102A mass spectrometer. Elemental analyses were performed at the National Chen-Kung University, Tainan, Taiwan.

\subsection{Preparation of 2}

Under a nitrogen atmosphere, $n$-butyl lithium (0.68 mmol) was slowly added into a solution of 
1,4-dibromobenzene $(160 \mathrm{mg}, 0.68 \mathrm{mmol})$ in $5 \mathrm{ml}$ of toluene at $0{ }^{\circ} \mathrm{C}$. The resulting $p-\mathrm{BrC}_{6} \mathrm{H}_{4} \mathrm{Li}$ reagent was then added into a solution of $1(200 \mathrm{mg}, 0.336 \mathrm{mmol})$ in $20 \mathrm{ml}$ of THF. The mixture was stirred at $50{ }^{\circ} \mathrm{C}$ for $5 \mathrm{~h}$, followed by addition of $\mathrm{MeOH}(2 \mathrm{ml})$. The solvent was removed under vacuum and the residue subjected to column chromatography (silica gel), with $n$-hexane/dichloromethane/ethyl acetate $(3: 1: 1)$ as eluant. Compound $2(75 \mathrm{mg}, 30 \%)$ was obtained from the second green band. Anal. Calc. for $\mathrm{C}_{30} \mathrm{H}_{23} \mathrm{BrFe}_{4} \mathrm{O}_{4}$ : C, 47.99; $\mathrm{H}, 3.09$. Found: $\mathrm{C}, 47.62 ; \mathrm{H}, 3.04 \%$. IR $\left(\mathrm{CH}_{2} \mathrm{Cl}_{2}, v_{\mathrm{CO}}\right)$ : $1636 \mathrm{~cm}^{-1} .{ }^{1} \mathrm{H}$ NMR $\left(\mathrm{CDCl}_{3}, 25{ }^{\circ} \mathrm{C}\right): 7.62(\mathrm{~d}, 2 \mathrm{H}$, $\left.J_{\mathrm{H}-\mathrm{H}}=10 \mathrm{~Hz}\right), 7.55\left(\mathrm{~d}, 2 \mathrm{H}, J_{\mathrm{H}-\mathrm{H}}=10 \mathrm{~Hz}, \mathrm{C}_{6} \mathrm{H}_{4}\right), 4.96$ (br, $2 \mathrm{H}), 4.86\left(\mathrm{br}, 2 \mathrm{H}, \mathrm{C}_{5} \mathrm{H}_{4}\right), 4.59(\mathrm{~s}, 15 \mathrm{H}, \mathrm{Cp}) \mathrm{ppm}$. ${ }^{13} \mathrm{C}\left\{{ }^{1} \mathrm{H}\right\} \quad \mathrm{NMR}\left(\mathrm{CDCl}_{3}, 25{ }^{\circ} \mathrm{C}\right): 290.8,290.5\left(\mu_{3}-\mathrm{CO}\right)$, $131.5,131.3,127.9,122.3\left(\mathrm{C}_{6} \mathrm{H}_{4}\right), 104.4,100.6,95.2$ $\left(\mathrm{C}_{5} \mathrm{H}_{4}\right), 99.1$ (Cp) ppm. MS (FAB) $m / z 750\left[\mathrm{M}^{+},{ }^{79} \mathrm{Br}\right]$.

\subsection{Preparation of $\mathbf{3}$}

Under a nitrogen atmosphere, $n$-butyl lithium $(0.35$ mmol) was slowly added into a solution of $2(126 \mathrm{mg}$, $0.16 \mathrm{mmol}$ ) in $5 \mathrm{ml}$ of toluene at $0{ }^{\circ} \mathrm{C}$. The mixture was stirred at room temperature for $1 \mathrm{~h}$, followed by addition of $\mathrm{MeOH}(1 \mathrm{ml})$. The reaction was worked up in a fashion identical with that above. Compound 3 (56 mg, $40 \%$ ) was obtained from the first green band. Anal. Calc. for $\mathrm{C}_{34} \mathrm{H}_{31} \mathrm{BrFe}_{4} \mathrm{O}_{4}$ : C, 50.61; H, 3.87. Found: C, $51.03 ; \mathrm{H}, 3.95 \%$. IR $\left(\mathrm{CH}_{2} \mathrm{Cl}_{2}, v_{\mathrm{CO}}\right): 1634 \mathrm{~cm}^{-1} \cdot{ }^{1} \mathrm{H}$ NMR $\left(\mathrm{CDCl}_{3}, 25{ }^{\circ} \mathrm{C}\right): 7.61(\mathrm{~d}, 2 \mathrm{H}), 7.56(\mathrm{~d}, 2 \mathrm{H}$, $\left.J_{\mathrm{H}-\mathrm{H}}=10 \mathrm{~Hz}, \mathrm{C}_{6} \mathrm{H}_{4}\right), 4.93(\mathrm{~m}, 2 \mathrm{H}),, 4.82(\mathrm{~m}, 2 \mathrm{H}$, $\left.\mathrm{C}_{5} \mathrm{H}_{4}\right), 4.52(\mathrm{~s}, 10 \mathrm{H}, \mathrm{Cp}), 4.46(\mathrm{~m}, 2 \mathrm{H}), 4.30(\mathrm{~m}$, $\left.2 \mathrm{H}, \mathrm{C}_{5} \mathrm{H}_{4}\right), 2.43\left(\mathrm{t}, 2 \mathrm{H}, J_{\mathrm{H}-\mathrm{H}}=12 \mathrm{~Hz}\right), 1.26(\mathrm{~m}, 4 \mathrm{H})$, $0.93\left(\mathrm{t}, 3 \mathrm{H}, J_{\mathrm{H}-\mathrm{H}}=12 \mathrm{~Hz}, \mathrm{Bu}\right) \mathrm{ppm}$. MS (FAB) $m / z 806$ $\left[\mathrm{M}^{+},{ }^{79} \mathrm{Br}\right]$.

\subsection{Preparation of $\mathbf{4}$}

Under a nitrogen atmosphere, $n$-butyl lithium (1.74 mmol) was slowly added into a solution of 1,4-dibromobenzene ( $200 \mathrm{mg}, 0.85 \mathrm{mmol})$ in $5 \mathrm{ml}$ of toluene at $0{ }^{\circ} \mathrm{C}$. The mixture was heated at $50{ }^{\circ} \mathrm{C}$ for $4 \mathrm{~h}$ to result in a pale yellow precipitate of $p-\mathrm{C}_{6} \mathrm{H}_{4} \mathrm{Li}_{2}$. The supernatant was removed by a syringe, and the solid washed with freshly distilled toluene $(3 \times 5 \mathrm{ml})$. A solution of 1 (150 $\mathrm{mg}, 0.251 \mathrm{mmol})$ in $40 \mathrm{ml}$ of THF was added. The resulting mixture was vigorously stirred at $50{ }^{\circ} \mathrm{C}$ for $5 \mathrm{~h}$, followed by addition of $\mathrm{MeOH}(2 \mathrm{ml})$. The reaction was worked up in a fashion identical with that above. Compound 4 (38 mg, 24\%) was obtained from the fourth green band. Anal. Calc. $\mathrm{C}_{54} \mathrm{H}_{42} \mathrm{Fe}_{8} \mathrm{O}_{8}$ : C, 51.24; $\mathrm{H}, 3.34$. Found: $\mathrm{C}, 50.93 ; \mathrm{H}, 3.58 \%$. IR $\left(\mathrm{CH}_{2} \mathrm{Cl}_{2}, v_{\mathrm{CO}}\right)$ : $1632 \mathrm{~cm}^{-1} .{ }^{1} \mathrm{H}$ NMR $\left(\mathrm{CDCl}_{3}, 25{ }^{\circ} \mathrm{C}\right): 7.78(\mathrm{~s}, 4 \mathrm{H}$, $\mathrm{C}_{6} \mathrm{H}_{4}$ ), 5.01 (br, $\left.4 \mathrm{H}\right), 4.86$ (br, $\left.4 \mathrm{H}, \mathrm{C}_{5} \mathrm{H}_{4}\right), 4.55$ (s, 30H, Cp) ppm. MS (FAB) $m / z 1266\left[\mathrm{M}^{+}\right]$.
Table 2

Crystal data and refinement details for $\mathbf{4}$

\begin{tabular}{ll}
\hline Formula & $\mathrm{C}_{54} \mathrm{H}_{42} \mathrm{Fe}_{8} \mathrm{O}_{8}$ \\
$T(\mathrm{~K})$ & $150(1)$ \\
Crystal system & $\mathrm{Rhombohedral}$ \\
Crystal solvent & $4\left(\mathrm{C}_{6} \mathrm{H}_{6}\right)+0.67\left(\mathrm{CHCl}_{3}\right)$ \\
Space group & $R \overline{3}$ \\
Unit cell dimensions & \\
$\quad a(\AA)$ & $33.696(1)$ \\
$\quad b(\AA)$ & $33.696(1)$ \\
$\quad c(\AA)$ & $15.0885(5)$ \\
$\gamma\left({ }^{\circ}\right)$ & 120 \\
$V\left(\AA^{3}\right)$ & $14836.6(8)$ \\
$Z$ & 9 \\
$D_{\text {calc }}(\mathrm{g}$ cm & -3 \\
$F(000)$ & 1.670 \\
Radiation $\lambda(\AA)$ & 7602 \\
$\mu\left(\mathrm{mm}^{-1}\right)$ & 0.71073 \\
$\theta$ range $\left(^{\circ}\right)$ & 1.849 \\
$R_{1}$ & $1.21-27.50$ \\
$w R_{2}$ & 0.0470 \\
Goodness-of-fit on $F^{2}$ & 0.1133 \\
\hline
\end{tabular}

\subsection{Cyclic voltammetric measurements for $\mathbf{2}$ and $\mathbf{4}$}

Electrochemical measurements were taken with a CV $50 \mathrm{~W}$ system. Cyclic voltammetry was performed with a Pt button working electrode, a Pt-wire auxiliary electrode, and an $\mathrm{Ag} / \mathrm{AgCl}$ reference electrode. The experiments were carried out with $1 \mathrm{mM}$ of $\mathbf{2}$ and $\mathbf{4}$, respectively, in dry $\mathrm{CH}_{2} \mathrm{Cl}_{2}$ solvent containing $0.1 \mathrm{M}(n$ $\left.\mathrm{C}_{4} \mathrm{H}_{9}\right)_{4} \mathrm{NPF}_{6}$ as the supporting electrolyte. Potential was scanned at $100 \mathrm{mV} \mathrm{s}^{-1}$ at $27^{\circ} \mathrm{C}$.

\subsection{Structure determination for 4}

A crystal of 4 with approximate dimensions of $0.5 \times 0.08 \times 0.08 \mathrm{~mm}^{3}$ was mounted in a thin-walled glass capillary and aligned on the Bruker Smart ApexCCD diffractometer with graphite-monochromated $\mathrm{Mo}-\mathrm{K}_{\alpha}$ radiation $(\lambda=0.71073 \AA$ A). The data were collected at $150 \mathrm{~K}$. All data were corrected for the effects of absorption. The structures were solved by the direct method and refined by full-matrix least-square on $F^{2}$. The program used was the SHELXTL package [18]. All non-hydrogen atoms were refined with anisotropic displacement parameters. Hydrogen atoms were included but not refined. A summary of relevant crystallographic date is provided in Table 2.

\section{Supplementary material}

Crystallographic data for the structural analysis of $\mathbf{4}$ has been deposited with the Cambridge Crystallographic Data Centre, CCDC No. 217582. Copy of this information may be obtained free of charge from The Director, CCDC, 12 Union Road, Cambridge CB2 1EZ, 
UK (fax: +44-1223-336033 or e-mail: deposit@ccdc. cam.ac.uk or www: http://www.ccdc.cam.ac.uk).

\section{Acknowledgements}

We are grateful for support of this work by the National Science Council of Taiwan.

\section{References}

[1] R.B. King, Inorg. Chem. 5 (1966) 2227.

[2] J.A. Ferguson, T.J. Meyer, Chem. Commun. (1971) 623.

[3] J.A. Ferguson, T.J. Meyer, J. Am. Chem. Soc. 94 (1972) 3409.

[4] R.D. Adams, F.A. Cotton (Eds.), Catalysis by Di-and Polynuclear Metal Cluster Compounds, Wiley-VCH, New York, 1998.

[5] D.W. Bruce, D. O'Hare (Eds.), Inorganic Materials, Wiley, Chichester, 1997.
[6] S. Onaka, M. Otsuka, Chem. Lett. (1995) 269.

[7] D.F. Shriver, H.D. Kaesz, R.D. Adams, The Chemistry of Metal Cluster Complexes, VCH, New York, 1990.

[8] P. Braunstein, L.A. Oro, P.R. Raithby, Metal Clusters in Chemistry, Wiley-VCH, Weinheim, 1999.

[9] N.T. Lucas, E.G.A. Notaras, S. Petrie, R. Stranger, M.G. Humphrey, Organometallics 22 (2003) 708.

[10] M. Hidai, S. Kuwata, Y. Mizobe, Acc. Chem. Res. 33 (2000) 46.

[11] M.D. Westmeyer, M.A. Massa, T.B. Rauchfuss, S.R. Wilson, J. Am. Chem. Soc. 120 (1998) 114.

[12] W.-Y. Yeh, C.-Y. Wu, L.-W. Chiou, Organometallics 18 (1999) 3547.

[13] J.J. Eisch, B.W. Kotowicz, Eur. J. Inorg. Chem. (1998) 761.

[14] M.A. Neuman, Trinh-Toan, L.F. Dahl, J. Am. Chem. Soc. 94 (1972) 3383.

[15] Trinh-Toan, W.P. Fehlhammer, L.F. Dahl, J. Am. Chem. Soc. 94 (1972) 3389.

[16] W.H. Morrison Jr., S. Krogsrud, D.N. Hendrickson, Inorg. Chem. 12 (1973) 1998.

[17] A. Togni, T. Hayashi (Eds.), Ferrocenes, VCH, Weinheim, 1995.

[18] G.M. Sheldrick, shelXtL-97, University of Göttingen, Germany, 1997. 